

\section{Sumário}

I. Crônicas do Direito Internacional ...............................................1

REPARAÇÃo DE VÍTIMAS À LUZ DE UM TRATAdo SOBRE EMPRESAS E DIREITOS HUMANOS ............ 3 Ana Cláudia Ruy Cardia

Consumer Social Responsibility as a Requirement for Corporate Social ResponsibiliTY

Nitish Monebhurrun

Crisis in Venezuela: The Brazilian response to the massive flow of Venezuelans in

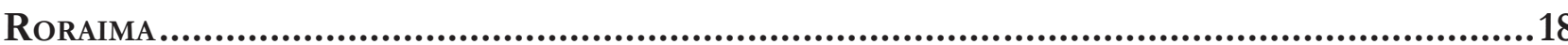

Jacqueline Salmen Raffoul

II. Dossiê EsPecial: Business and Human Rights.........................................23

Some remarks on the third sessions of the Business and Human Rights Treaty Pro-

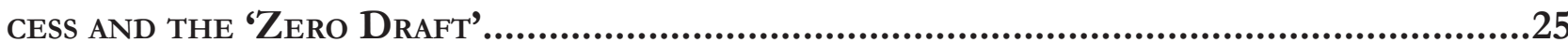

Humberto Cantú Rivera

The United Nations guiding principles on business and human Rights, the State

DUTY TO PROTECT HUMAN RIGHTS AND THE STATE-BUSINESS NEXUS.

Mihaela Maria Barnes

HARdening SOFT LAW: ARE THE EMERging Corporate SOCIAL DisClOSURE LAWS CAPABLE OF GENERATING SUBSTANTIVE COMPLIANCE WITH HUMAN RIGHTS?

Justine Nolan

Del Documento de Elementos al Draft 0: apuntes jurídicos respecto del posible CONTENIDO DEL PROYECTO DE INSTRUMENTO VINCULANTE SOBRE EMPRESAS TRANSNACIONALES

Y OTRAS EMPRESAS CON RESPECTO A LOS DERECHOS HUMANOS

Adoración Guamán 
ACCESS TO REMEDIES AND THE EMERGING ETHICAL DILEMMAS: CHANGING CONTOURS WITHIN THE BUSINESS-HUMAN RIGHTS DEBATE

Justin Jos

LA RESPONSABILIDAD PENAL DE LAS EMPRESAS POR GRAVES VIOLACIONES DE DERECHOS HUMANOS: PRÁCTICA ACTUAL Y DESAFÍOS FUTUROS 130

Daniel Iglesias Márquez

THE ENVIRONMENTAL LAW DIMENSIONS OF AN INTERNATIONAL BINDING TREATY ON BUSINESS AND HUMAN RIGHTS

Juan Gabriel Auz Vaca

Los Objetivos de Desarrollo Sostenible en Europa y su Intersección con el Marco de los Negocios y los Derechos Humanos

Paolo Davide Farah

HumAN RIGHTS AND MARKET ACCESS 203

Danielle Mendes Thame Denny

BusinesS AND HUMAN RIGHTS IN BRAZIL: EXPLORING HUMAN RIGHTS DUE DILIGENCE AND OPERATIONAL-LEVEL GRIEVANCE MECHANiSMS IN THE CASE OF KinRoss PARACATU Gold Mine...222 Mariana Aparecida Vilmondes Türke

Human Rights and eXtractive industries in Latin America: What Responsibility of CORPORATIONS AND THEIR STATES OF ORIGIN FOR HUMAN RIGHTS VIOLATIONS IN THE INTER-American Human Rights System?.

Alberto do Amaral Junior e Viviana Palacio Revello

MultinaCiOnAIS FAST FASHION E DIREITOS HUMANOS: EM BUSCA DE NOVOS PADRÕES DE RESPONSABILIZAÇÃO 255

Laura Germano Matos e João Luis Nogueira Matias

III. Artigos sobre outros temas

EFFICIENCY AND EFFICACY OF PUBLIC FOOD PROCUREMENT FROM FAMILY FARMERS FOR SCHOOL FEEDING IN BRAZIL. 271

Rozane Márcia Triches 
A relaÇão ENTRE O GRAU de INTEGRaÇÃo ECONÔMiCA E O SISTEMA DE SOLUÇÃo DE CONTROvÉRSIAS: UM ESTUdo COMPARATIVO ENTRE A UNIÃo EURopeia E O MERCOSUl.....................286

Luciane Klein Vieira e Elisa Arruda

THE RIGHTS TO MEMORY AND TRUTH IN THE INTER-AMERICAN PARADIGMS OF TRANSITIONAL JUSTICE: THE CASES OF BRAZIL AND CHILE 308

Bruno Galindo

Juliana Passos de Castro

A margem nacional de apreciação na Corte Interamericana de Direitos Humanos.325 Gilberto Schäfer, José Eduardo Aidikaitis Previdellie e Jesus Tupã Silveira Gomes

Novos Direitos FUNDAMENTAIS NO ÂMBITo DA UNASUL: ANÁLISE DAS AGENDAS DE Brasil E VENEZUELA À LUZ DO DIREITO À PAZ.

Pedro Pulzatto Peruzzo e Arthur Ciciliati Spada

A atuação do Grupo Mercado Comum frente À Criminalidade organizada transnacio-

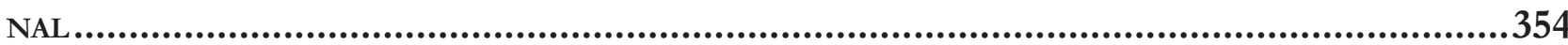

Sabrina Cunha Kesikowski, Luis Alexandre Carta Winter e Eduardo Biacchi Gomes

COUNTER-TERRORISM LEGISLATION AND TERRORIST ATTACKS: DOES HUMAN RIGHTS HAVE SPACE?

Heloisa Tenello Bretas e Daniel Damásio Borges

Territórios da ViolênCia de GÊNERo: NORMATIVA INTERNACIONAL E os Casos "CAMpo AlGodoeiro” (MÉXICO) - “Morro do Garrote” (BrasiL)

Eugênia Nogueira do Rêgo Monteiro Villa e Bruno Amaral Machado

O USO DE MECANISMOS INFORMAIS DE GOVERNANÇA GLOBAL E SUA APLICABILIDADE NAS LICITAÇÕES PÚBLICAS BRASILEIRAS.

Fabiano de Figueiredo Araujo e Paulo Afonso Cavichioli Carmona

Autonomia INSTITUCIONAL DA IGREJA CATÓliCA E A INGERÊNCIA INDEVIDA DO ESTADO BRASILEIRo POR EVENTUAIS Ilícitos CANÔNicos: ANÁlise do CASO de Formosa-GO, À luz do TraTADo Brasil-Santa SÉ de 2010 
A MORE TARGETED APPROACH TO FOREIGN DIRECT INVESTMENT: THE ESTABLISHMENT OF SCREENING SYSTEMS ON NATIONAL SECURITY GROUNDS

Carlos Esplugues Mota

IV. RESENHAS 467

Direito Internacional em Perspectiva Transcivilizacional de Yasuaki Onuma........469 Arthur Roberto Capella Giannattasio

Resenha do livro Space, Global Life: The Everyday Operation of International LaW and Development, de Luis Eslava .473

Matheus Gobbato Leichtweis

QUEM TEM MEDO DO PÓS-COLONIAL NO DIREITO INTERNACIONAL? UMA RESENHA DE "DECOLONISING INTERNATIONAL LAW: DEVELOPMENT, ECONOMIC GROWTH AND THE POLITICS OF UNIVERSAlity" de Sundhya Pahuja

Gabriel Antonio Silveira Mantelli

Direitos humanos COMO UM NOVO PROJETO PARA O Direito INTERNACIONAL? Notas sobre The Last Utopia, de Samuel Moyn .490 João Roriz 


\title{
Efficiency and efficacy of public food procurement from family farmers for school feeding in Brazil*
}

\author{
Eficiência e eficácia da aquisição pública de \\ alimentos de agricultores familiares para a \\ alimentação escolar no Brasil
}

Rozane Márcia Triches** ***

\begin{abstract}
An evaluation of efficiency and efficacy of the implementation of article 14 of Law 11947/2009 was carried out in the southern region of Brazil. By performing quali-quantitative research with interviews, provision of accounts and public calls, the results demonstrate that efficiency is greater when there is strategic action of social actors and state permeability. Such purchases are effective, providing income to family farmers and food quality to schoolchildren.
\end{abstract}

Keywords: school feeding, family farming, food and nutrition security, public policies, public food procurement.

\section{Resumo}

* Recebido em 13/10/2018

Aprovado em 21/10/2018

** $\mathrm{PhD}$ in Nutrition, Rural Development Graduate Programme Associate Professor Universidade Federal da Fronteira Sul. E-mail: rozane.triches@gmail.com

*** In November 2016, the World Food Programme Centre of Excellence against Hunger in Brazil (WFP CoE) completed five years of existence. Since its foundation, the Centre of Excellence has been working to build countries' capacities to fight hunger and malnutrition through South-South and Triangular Cooperation, further contributing to achieve the Sustainable Development Goals (SDGs). In order to celebrate its anniversary, the WFP CoE, in partnership with the Universitary Centre of Brasilia (UniCEUB), launched a contest for researchers working with food and nutrition security (FNS) and related areas. This paper was the winner of the first place in the anniversary contest. It was considered a valuable contribution to research in FNS and to WFP's purpose of achieving Zero Hunger worldwide.
Uma avaliação de eficiência e eficácia da implementação do artigo 14 da Lei 11.947/2009 foi realizada na região sul do Brasil. Ao realizar pesquisas quali-quantitativas com entrevistas, prestação de contas e chamadas públicas, os resultados demonstram que a eficiência é maior quando há atuação estratégica dos atores sociais e permeabilidade do estado. Tais compras são eficazes, proporcionando renda aos agricultores familiares e qualidade alimentar aos escolares.

Palavras-chave: alimentação escolar, agricultura familiar, segurança alimentar e nutricional, políticas públicas, compras públicas de alimentos.

\section{INTRODUCTION}

In the last decades, school feeding programs (SFPs) have been one of the privileged spaces for rethinking development on a sustainable basis. Developed and developing countries have taken initiatives to bring food production and consumption closer to school through the purchasing from local family farmers. These actions are focused on shortening the food production chain and aim at promoting sustainability, rural development, local eating habits 
appreciation, quality improvement of the meals served and cognitive performance of schoolchildren ${ }^{1}$.

This new approach to SFPs has been designated in the international literature as Home-Grown School Feeding (HGSF) ${ }^{2}$. The basic premise behind it is that low productivity, fragile development of local agricultural markets and limited nutritional and educational outcomes are mutually reinforced and determine hunger and poverty. HGSF would work as a synergistic link between development goals and public health goals through SFPs. Accordingly, the State would use public procurement for sustainable development.

For Morgan (2006) ${ }^{3}$, sustainable development should be understood as having multiple dimensions, including social, economic, environmental and political ones. For the author, it is a political project to create a "Green Sta$t e$ ", defined in generic terms as a democratic State in which regulatory ideals and procedures are informed by ecological democracy, rather than liberal democracy.

With such actions, the state would cooperate on the concept of sustainable diets, which, according to

1 See: Sonnino, R., T.L. Bassinello \& C. Lozano. 2016. "School Feeding Programmes: addressing the challenges of sustainable development." In Alimentação Escolar: construindo interfaces entre saúde, educação e desenvolvimento, 35-64. Chapecó: Argos; Morgan, K\& R. Sonnino. 2008. The school food revolution: public food and the challenge of sustainable development. London: Earthscan; Espejo, F., C. Burbano \& E. Galliano. 2009. Home-Grown School Feeding: A framework to link school feeding with local agricultural production. Rome: WFP; Izumi, B.T., D.W.Wright \& M.W. Hamm. 2010. "Market diversification and social benefits: motivations of farmers participating in farm to school programs." Journal of Rural Studies, 26:374-382. Accessed 18 August 2016. http:/ / www.sciencedirect.com/science/article/pii/S0743016710000161; Triches, R.M. \& S. Schneider. 2010. "Alimentação Escolar e Agricultura Familiar: reconectando o consumo à produção." Saúde e Sociedade, 19(4): 933-945. Accessed 10 January 2016. doi: http://dx.doi.org/10.1590/ S0104-12902010000400019; International Policy Centre for Inclusive Growth (IPC - IG). 2013. Structured Demand and Smallholder Farmers in Brazil: the Case of FPP and NSFP. Brasilia: IPC-IG; Otsuki, K. 2011. "Sustainable partnerships for a green economy: A case study of public procurement for home-grown school feeding." Natural Resources Forum, 35(3):213-222. Accessed 20 September 2016. doi:10.1111/j.1477-8947.2011.01392.x.

2 See: Bundy, D., C. Burbano, M. Grosh, A. Gelli, M. Jukes \& L. Drake. 2009. Rethinking school feeding: social safety nets, child development, and the education sector. Washington: World Bank Publications; Espejo, F., C. Burbano \& E. Galliano. 2009. HomeGrown School Feeding: A framework to link school feeding with local agricultural production. Rome: WFP.

3 Morgan, K. 2006. "School Food and public domain: the politics of the public plate." The political quarterly, 77:379-387. Accessed 10 November 2016. doi:10.1111/j.1467-923X.2006.00809.x.
Burlingame \& Dernini $(2012)^{4}$, are those with low environmental impact, that contribute to food and nutrition security and healthy living for future generations. Sustainable diets are protective and respectful of biodiversity and ecosystems, culturally acceptable, economically affordable and fair, nutritionally adequate, safe and healthy, while optimising natural and human resources.

Particularly in Brazil, the National School Feeding Program (in Portuguese, Programa Nacional de Alimentação Escolar - PNAE) has existed for more than 60 years. Although it was created in 1955, until 2009, PNAE's purchasing processes benefited, ultimately, retail and wholesale markets - that supplied mostly industrialized and deterritorialized products to the Programme.

From the decentralization of food programmes in 1994, a process of reviewing public food procurement in Brazil began. However, this was only effectively implemented with the establishment of Food and Nutrition Security (FNS) policies in the country. In 2003, the Food Procurement Programme (in Portuguese, Programa de Aquisiz̧ão de Alimentos - PAA) was created, aiming to facilitate the process of food purchases from family farmers in Brazil. This stimulated a discussion about PNAE's procurement process, and - from the point of view of local/regional development and food security - it was deemed appropriate that PNAE also adopted strategies to encourage purchasing from smallholder farmers. Accordingly, Law 11947 of $2009^{5}$ established the obligation to use at least $30 \%$ of PNAE's financial resources for purchases from family farmers (Article 14). In the wake of these reviews of public food procurement, Decree 8.473 of 2015 stipulated a new modality of purchases: Institutional Purchasing. As in PNAE's regulation, this decree defines that all public institutions that purchase food (universities, hospitals, prisons, nursing homes, etc.) should invest a minimum of $30 \%$ of their resources in buying products from family farmers (FFs).

From the point of view of policies and legislation,

4 Burlingame, B. \& S. Dernini. 2012. "Sustainable Diets and Biodiversity: Directions and Solutions for Policy, Research and Action." Proceedings of the International Scientific Symposium 'Biodiversity and Sustainable Diets United against Hunger'. FAO Headquarters, Rome: FAO and Bioversity International.

5 Brasil. Lei no 11947 de 16 de junho de 2009. 2009. Dispõe sobre o atendimento da alimentação escolar e do Programa Dinheiro Direto na Escola aos alunos da educação básica. Diário Oficial da União. Brasília - DF. Accessed 15 October 2016. http://www.planalto.gov.br/ccivil_03/_ato2007-2010/2009/lei/111947.htm 
Brazil has stood out at the global level for providing universal free school meals which are locally produced by $\mathrm{FFs}^{6}$. However, although legal support is important as a tool for sustainable development, it must be accompanied by other legal, institutional and action support from social actors to actually take effect. Based on this assumption and considering that there are still few studies that evaluate school meals as a policy, this article intends to evaluate the implementation of article 14 of Law 11947/2009, by identifying how it has been occurring in the country. The objective here is to develop an in-depth study of the southern region of Brazil - composed of the Rio Grande do Sul (RS), Santa Catarina (SC), and Paraná (PR) states -, by analysing the efficiency of their procurement processes (which problems they encounter and how they have been resolved) and whether efficacy in providing quality food and benefiting family farmers is achieved. This region was chosen because it is the most successful in Brazil in terms of purchasing family farming products through PNAE.

This article starts from this introduction and describes the methods of the study. Then, it analyses the Brazilian evolution in relation to compliance with article 14 of the above-mentioned Law. The following two sections evaluate the efficiency of the process of public food procurement for school feeding and identify its progress in achieving sustainable purchasing. The difficulties reported by the actors involved in these purchases in selected municipalities and the ways they manage to overcome them are analysed. After that, the policy efficacy is examined, by taking notice of links established between it and the benefits related to food and nutrition security of schoolchildren and farmers.

\section{Methods}

This study is of a qualitative and quantitative nature and its analysis is based on secondary and primary data ${ }^{7}$. To identify compliance with Article 14 of Law

6 See: Sonnino, R., T.L. Bassinello \& C. Lozano. 2016. "School Feeding Programmes: addressing the challenges of sustainable development." In Alimentação Escolar: construindo interfaces entre saúde, educação e desenvolvimento, 35-64. Chapecó: Argos; Food and Agriculture Organization (FAO). 2015. Las compras públicas a la agricultura familiar y la seguridad alimentaria y nutricional em America Latina y el Caribe: lecciones aprendidas y experiências. Brasilia: FAO.

7 This study was funded by the Scientific and Technological Re-
11947/2009, we used documents and Provision of Accounts information available on the website of the National Fund for the Educational Development ${ }^{8}$ (in Portuguese, Fundo Nacional de Desenvolvimento da Educação - FNDE), for the period of 2011 to 2016 .

After analysing the level of compliance with the law at the country level, the three southern states - Paraná, Santa Catarina and Rio Grande do Sul - were further evaluated. Also, Public Calls (PCs) data of 2013 from these states were collected through their municipalities' websites, departments of education and telephone calls. For that, a sampling of the municipalities of each state was carried out. A sample of approximately $5 \%$ of the city offices of the states was considered, by carefully establishing a stratification between them according to the macro regions and population, so that about $10 \%$ of the student body was considered. In these PC documents, the following items were analysed: a) products requested, according to degree of processing; B) adequacy of PCs regarding information on periodicity, delivery points and the presence of prices to be paid for the food.

After collecting this information, the quantitative data was tabulated and analysed using simple descriptive statistics on Microsoft Excel. The data was presented in absolute and relative frequencies.

Regarding the qualitative component of this research, eight municipalities from each state were chosen to conduct the interviews with the actors involved in the implementation of Article 14 of Law 11947/2009.

These municipalities were chosen to contemplate the following criteria:

a) Different population sizes, according to the following stratification: Group 1 - very small municipalities (with less than 20,000 inhabitants); Group 2 - small municipalities (from 20,000 to 100,000 inhabitants); Group 3 - medium-sized municipalities (from 100,000 to 500,000 inhabitants); Group 4 - large municipalities (with 500,000 or more inhabitants).

b) The diversity of macro-regions of each state.

Hence, the municipalities presented in Table 1 were selected.

search Project developed from the Calls MCTI-CNPq / MDS-SAGI No 24/2013 Social Development and Call MCTI / Transversal Action-LEI/ CNPq No 82/2013 Food and Nutrition Security in the field of UNASUR and AFRICA.

8 www.fnde.gov.br 
Table 1 - Municipalities participating in the research and their respective populations, 2016.

\begin{tabular}{|c|c|c|c|c|c|}
\hline \multicolumn{2}{|c|}{ Paraná } & \multicolumn{2}{c|}{ Rio Grande do Sul } & \multicolumn{2}{c|}{ Santa Catarina } \\
\hline $\begin{array}{c}\text { Munici- } \\
\text { pality }\end{array}$ & $\begin{array}{c}\text { Number } \\
\text { of inha- } \\
\text { bitants }\end{array}$ & $\begin{array}{c}\text { Munici- } \\
\text { pality }\end{array}$ & $\begin{array}{c}\text { Number } \\
\text { of inha- } \\
\text { bitants }\end{array}$ & $\begin{array}{c}\text { Munici- } \\
\text { pality }\end{array}$ & $\begin{array}{c}\text { Number } \\
\text { of inha- } \\
\text { bitants }\end{array}$ \\
\hline Curitiba & $1,746,896$ & $\begin{array}{c}\text { Porto } \\
\text { Alegre }\end{array}$ & $1,409,351$ & Joinville & 515,288 \\
\hline Londrina & 506,645 & $\begin{array}{c}\text { Caxias do } \\
\text { Sul }\end{array}$ & 435,564 & Chapecó & 183,530 \\
\hline Cascavel & 286,172 & Pelotas & 328,275 & Lages & 156,727 \\
\hline $\begin{array}{c}\text { Apuca- } \\
\text { rana }\end{array}$ & 120,884 & $\begin{array}{c}\text { Cara- } \\
\text { zinho }\end{array}$ & 59,317 & Miguel do & 36,306 \\
\hline $\begin{array}{c}\text { Assis } \\
\text { Chateau- } \\
\text { briand }\end{array}$ & 33,028 & $\begin{array}{c}\text { Oão } \\
\text { Gabriel }\end{array}$ & 60,425 & Maravilha & 22,101 \\
\hline $\begin{array}{c}\text { Laranjei- } \\
\text { ras do } \\
\text { Sul }\end{array}$ & 30,783 & Gramado & 32,273 & $\begin{array}{c}\text { Pinhal- } \\
\text { zinho }\end{array}$ & 16,332 \\
\hline $\begin{array}{c}\text { Urai } \\
\text { Sulina }\end{array}$ & 11,472 & Herval & 6,753 & $\begin{array}{c}\text { Coronel } \\
\text { Freitas }\end{array}$ & 10,213 \\
\hline $\begin{array}{c}\text { Source: Prito } \\
\text { ra Alta }\end{array}$ & 6,402 & Cordilhei- & 3,787 \\
\hline
\end{tabular}

Source: Prepared by the author, 2017.

Representatives of the school feeding services such as managers and/or nutritionists of the municipal school feeding sector, councillors of the city's Council of School Feeding (CSF) (regardless of the segment represented - parents, teachers, civil society), rural extension practitioners, and family farmers participated in the research. Thus, four to five actors were interviewed in each municipality surveyed.

For each group of social actors, differentiated semi-structured interview guides were applied. The interview topics included, among others: the changes in the menu and the functioning of the local school feeding service, the difficulties in implementing Article 14, the level of participation of social actors and their experience with PNAE, as well as their difficulties in integrating the program and the benefits achieved. The qualitative data was analysed and categorised by themes, according to a content analysis technique, using the NVivo 8 software.

\section{EVOLUTION OF PUBLIC PURCHASING FROM FAMILY FARMERS FOR SCHOOL FEEDING, FROM 2010 TO 2016}

According to data from FNDE (2018), since the mandatory implementation of Article 14 by Executing Entities (EEs) in 2010, there has been a growing increase in the resources used by PNAE to purchase products from FFs. In 2016 (most recent data available), the amount used for such purpose at the country level was BRL $858,777,139.55$, that is, $22.12 \%$ of the total amount invested by the federal government in PNAE (BRL 3,882,673,284.31). This means an increase of BRL 710,205,616.21 compared to 2010, when only $4.9 \%$ (BRL 148,571,523.34) of the federal funds for such purchases were used.

Chart 1 shows the growth of resources allocated to family agriculture from 2011 to 2016, relatively to the regions of the country ${ }^{9}$. It is noticeable that, according to FNDE (2018) data, the total percentage of purchases grew upward (but with some fluctuations in the last two years). The exception to this trend was the Central-West region, where the percentage of 2013 appears to be higher than in 2014, decreasing progressively in the following years ${ }^{10}$. When comparing regions, we cansee that the South region differs from the others nearly every year, and it is the only one which was able to reach, since 2014, the minimum amount provided by law to be spent on food from family farming. On the other hand, the Central-West region is the one with the lowest growth of these figures in the time evaluated, as it used only $16.36 \%$ of the resources in 2016 , thus failing to comply with the legislation (considering the total amount received by its EEs).

9 The referred resources are those sent by the FNDE to all EEs state entities (State Department to the state schools), municipal entities (municipal schools) and even federal entities (federal schools) - that exist within each federated state.

10 We have identified that, according to FNDE spreadsheets (2016), in the year of 2013, the State Department of Education of Goiás appears to have used more than $100 \%$ of its funds - received from the federal government - to buy products from family farmers. However, in the provision of accounts, it was verified that, in its Physical-Financial Statement states, the same EE did not reach the minimum of $30 \%$ required by law, which suggests a discrepancy of information. Thus, it appears that an error occurred in computing this data in the spreadsheets elaborated by the FNDE. This information is likely to be incorrect, and the important amount it represents in spending (BRL $40,989,364.80)$ explains the greater volume of resources spent in the Central-West region in 2013, as compared to 2014. 


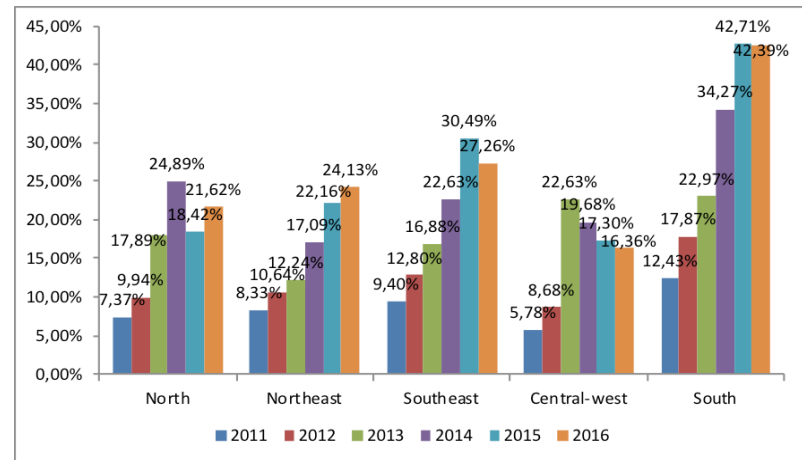

Chart 1: Aggregate percentage of resources used for purchases of family agriculture products for school feeding, coming from the EEs of the states of each region of the country - 2011 to 2016.

In Table 2, the differences between the states of each region can be identified. It is noteworthy that the most successful states in compliance with the Law are in three regions: in the North Region (Acre and Roraima states), in the Southeast (Espírito Santo and Minas Gerais state) and in the South region (Paraná, Santa Catarina and Rio Grande do Sul states).

Table 2: Aggregate percentage of resources used for purchases of family agriculture products for school feeding, coming from the EEs from of each state that composes the regions of the country - 2011 to 2016.

\begin{tabular}{|c|c|c|c|c|c|c|c|}
\hline Region & States & 2011 & 2012 & 2013 & 2014 & 2015 & 2016 \\
\hline \multirow{8}{*}{ North } & $\mathrm{AM}$ & $5,00 \%$ & $12,40 \%$ & $20,40 \%$ & $26,50 \%$ & $10,20 \%$ & $17,32 \%$ \\
\hline & $\mathrm{AC}$ & $6,90 \%$ & $4,90 \%$ & $31,10 \%$ & $35,40 \%$ & $16,60 \%$ & $18,66 \%$ \\
\hline & $\mathrm{RR}$ & $3,60 \%$ & $9,00 \%$ & $8,90 \%$ & $38,70 \%$ & $16,85 \%$ & $28,42 \%$ \\
\hline & RO & $6,10 \%$ & $6,90 \%$ & $22,50 \%$ & $23,20 \%$ & $34,45 \%$ & $32,45 \%$ \\
\hline & PA & $7,60 \%$ & $13,70 \%$ & $18,40 \%$ & $22,70 \%$ & $24,00 \%$ & $23,04 \%$ \\
\hline & TO & $16,40 \%$ & $18,20 \%$ & $18,80 \%$ & $23,40 \%$ & $16,80 \%$ & $15,38 \%$ \\
\hline & AP & $6,00 \%$ & $4,50 \%$ & $5,10 \%$ & $4,30 \%$ & $10,02 \%$ & $16,07 \%$ \\
\hline & Total & $7,37 \%$ & $9,94 \%$ & $17,89 \%$ & $24,89 \%$ & $18,42 \%$ & $21,62 \%$ \\
\hline \multirow{10}{*}{$\begin{array}{l}\text { Northe- } \\
\text { ast }\end{array}$} & $\mathrm{BA}$ & $7,10 \%$ & $10,60 \%$ & $12,60 \%$ & $19,40 \%$ & $24,32 \%$ & $24,15 \%$ \\
\hline & $\mathrm{CE}$ & $9,90 \%$ & $14,20 \%$ & $13,10 \%$ & $20,70 \%$ & $25,35 \%$ & $27,08 \%$ \\
\hline & MA & $5,20 \%$ & $6,60 \%$ & $14,00 \%$ & $17,00 \%$ & $24,18 \%$ & $24,02 \%$ \\
\hline & PI & $5,50 \%$ & $9,30 \%$ & $7,00 \%$ & $11,80 \%$ & $10,98 \%$ & $11,66 \%$ \\
\hline & $\mathrm{RN}$ & $14,40 \%$ & $17,80 \%$ & $16,20 \%$ & $20,50 \%$ & $16,28 \%$ & $17,37 \%$ \\
\hline & PB & $9,40 \%$ & $8,00 \%$ & $11,80 \%$ & $13,00 \%$ & $23,06 \%$ & $28,50 \%$ \\
\hline & $\mathrm{PE}$ & $3,60 \%$ & $7,30 \%$ & $12,60 \%$ & $16,20 \%$ & $20,77 \%$ & $20,12 \%$ \\
\hline & AL & $4,60 \%$ & $5,40 \%$ & $8,60 \%$ & $14,10 \%$ & $21,25 \%$ & $28,35 \%$ \\
\hline & $\mathrm{SE}$ & $15,30 \%$ & $16,60 \%$ & $14,30 \%$ & $21,10 \%$ & $33,26 \%$ & $35,91 \%$ \\
\hline & Total & $8,33 \%$ & $10,64 \%$ & $12,24 \%$ & $17,09 \%$ & $22,16 \%$ & $24,13 \%$ \\
\hline
\end{tabular}

\begin{tabular}{|c|c|c|c|c|c|c|c|}
\hline \multirow{5}{*}{ Southe- } & RJ & $2,30 \%$ & $4,60 \%$ & $8,00 \%$ & $11,10^{\circ} \%$ & $22,00 \%$ & $25,48 \%$ \\
\hline & $\mathrm{SP}$ & $6,30 \%$ & $8,90 \%$ & $12,00 \%$ & $16,80 \%$ & $26,55 \%$ & $16,04 \%$ \\
\hline & MG & $10,30 \%$ & $14,40 \%$ & $19,80 \%$ & $26,20 \%$ & $31,62 \%$ & $32,87 \%$ \\
\hline & ES & $18,70 \%$ & $23,30 \%$ & $27,70 \%$ & $36,40 \%$ & $41,81 \%$ & $34,66 \%$ \\
\hline & Total & $9,40 \%$ & $12,80 \%$ & $16,88 \%$ & $22,63 \%$ & $30,49 \%$ & $27,26 \%$ \\
\hline \multirow{5}{*}{$\begin{array}{l}\text { Central- } \\
\text { West }\end{array}$} & DF & $0,00 \%$ & $0,00 \%$ & $0,00 \%$ & $14,90 \%$ & $9,08 \%$ & $4,22 \%$ \\
\hline & GO & $8,20 \%$ & $12,30 \%$ & $57,30 \%$ & $19,70 \%$ & $18,16 \%$ & $18,73 \%$ \\
\hline & MT & $7,70 \%$ & $11,90 \%$ & $14,30 \%$ & $18,60 \%$ & $19,61 \%$ & $16,91 \%$ \\
\hline & MS & $7,20 \%$ & $10,50 \%$ & $18,90 \%$ & $25,50 \%$ & $22,36 \%$ & $25,57 \%$ \\
\hline & Total & $5,78 \%$ & $8,68 \%$ & $22,63 \%$ & $19,68 \%$ & $17,30 \%$ & $16,36 \%$ \\
\hline
\end{tabular}

\begin{tabular}{llllllll}
\hline \multirow{3}{*}{ South } & RS & $14,10 \%$ & $17,50 \%$ & $26,90 \%$ & $40,20 \%$ & $46,53 \%$ & $42,06 \%$ \\
\cline { 2 - 7 } & SC & $13,80 \%$ & $18,50 \%$ & $19,70 \%$ & $26,30 \%$ & $42,84 \%$ & $46,36 \%$ \\
\cline { 2 - 7 } & PR & $9,40 \%$ & $17,60 \%$ & $22,30 \%$ & $36,30 \%$ & $38,77 \%$ & $38,76 \%$ \\
\cline { 2 - 7 } & Total & $12,43 \%$ & $17,87 \%$ & $22,97 \%$ & $34,27 \%$ & $42,71 \%$ & $42,39 \%$ \\
\hline
\end{tabular}

If we consider the percentage of EEs that have been complying with the legislation, FNDE offers the following data: in 2010 they were only 15\%, and in 2016 this number increased to $44 \%$. However, still in 2016, $15 \%$ of EEs did not purchase anything from FFs and $41 \%$ did not reach the minimum rate of $30 \%$. According to Thies et al $(2016)^{11}$, the South region presents the highest percentages in all the years analysed and is above the national proportion in the entire period (2011: 59.1\%, 2012: 66.6\%, 2013: 64.0\%, 2014: 77.0\%). The same authors state that, in $2014,88.6 \%$ of the southern municipalities that received PNAE funds purchased from family agriculture for school feeding.

This data demonstrates that the legal requirement is very important for the growing number of EEs that seek to purchase from FFs, but it is not sufficient yet for effective compliance - both in the number of EEs that execute it and in the sum of all amounts used for purchases from FFs in the Brazilian regions or states. Therefore, the question that must be answered is: what are the remaining problems and the factors that help to overcome them? In that sense, the aim of this article is to identify how the food procurement process (Public Calls) has occurred, its obstacles and the role of ins-

11 Thies, V.F., C. Grisa, S. Schneider \& W. Belik. 2016. Potencial das compras públicas como mercado para a agricultura familiar uma análise do NSFP entre 2011-2014. Anais do $54^{\circ}$ Congresso da Sociedade Brasileira de Economia, Administração e Sociologia Rural: Maceió, Brazil. 
titutions and local actors in these arrangements in the most successful region of the country, by verifying their efficiency.

\section{Legal Change IN the processes of public FOOD PROCUREMENT FOR THE SFPS IN BRAZIL AND ITS OUTCOMES}

When studying the barriers to public procurement becoming sustainable, Morgan (2006) ${ }^{12}$ first considers "value for money" (lowest price), rather than "best value" (best quality considering environmental and social benefits). In that sense, for the author, even though purchasing local, seasonal, organic, fresh food may be more expensive than buying industrialized and conventional foods, this modality offers no perceived benefits to health and to the environment in the long term.

The second barrier to sustainable public procurement would be a lack of knowledge and qualification of the teams at the helm of the purchasing programs. Hence, many public-sector institutions would have professionals without qualifications or training to work in the public money management. All the other barriers, according to the author, would come from the lack of active political leadership. Accordingly, top leaders would reflect their lack of accountability regarding sustainable procurement on the organization under their responsibility. These barriers would help explain why sustainable public procurement would continue to be more of an inspiration than a reality in the public organisations.

Concerning Brazil, public procurement processes for the PNAE were associated exclusively with Law 8666 until 2009. This Law established rules for public biddings for purchase and contracts, and was sanctioned in June 1993. According to Herrmann (1998) ${ }^{13}$, it brought advancements to the disciplinary matters of the bidding procedures and the control of public agents' actions. This legal framework refers to the principles governing the acts of Public Administration in

12 Morgan, K. 2006. "School Food and public domain: the politics of the public plate." The political quarterly, 77:379-387. Accessed 10 November 2016. doi:10.1111/j.1467-923X.2006.00809.x. 13 Herrmann, I. 1998. Licitações públicas no Brasil: explorando o conceito de ineficiência por desenho. Anais III SemeAd: USP, São Paulo. the country's Administrative Law - legality, purpose, isonomy, administrative morality and publicity - and postulates, ultimately, privileging offers with the lowest price.

In conjunction with other FNS policies and the action of the National Council on Food and Nutrition Security, strategic government procurement from family farmers began to be targeted in the early 2000's. Hereafter, the Food Procurement Program (PAA) was instituted in 2003 (Law 10696) and had as its main objective to foster and reinforce family agriculture through a set of actions concerning: the purchase from family agricultural production, the product's distribution to vulnerable people and the contribution to build strategic food stocks in smallholder production. To do so, the Program used bidding exemption for purchasing from these farmers.

Thus, in an attempt to overcome the bureaucracy of the bidding processes, many municipalities used the PAA to supply the products for school meals of PNAE. With the PAA, a new legal framework was created that would allow a greater presence of the state in supporting the marketing processes of the family farmers' production, contributing to their sustainability and to the distribution to food insecure groups of people. PAA becomes, then, the first mechanism to promote local development based on government procurement, which further highlighted the great potential of PNAE to implement food security policies, by linking consumption and production. In conjunction with PAA, some local experiences have also fostered this discussion, as municipalities began to buy products from family farmers by adapting the current bidding process ${ }^{14}$.

These movements not only fostered the idea, but also became a reference for the formulation of Provisional Measure 455, of 28 January 2009, and later, Law 11947 of 16 June 2009, and Resolution 38 of 16 July 2009, which established compulsory public purchases of products from family farmers. ${ }^{15}$

14 See: Triches, R.M. \& S. Schneider. 2010. "Alimentação Escolar e Agricultura Familiar: reconectando o consumo à produção.” Saúde e Sociedade, 19(4): 933-945. Accessed 10 January 2016. doi: http://dx.doi.org/10.1590/S0104-12902010000400019; Triches, R.M. \& S. Schneider. 2012. "Desestruturar para construir: interfaces para a agricultura familiar acessar o programa de alimentação escolar." Estudos Sociedade e Agricultura, 20(1):66-105. Accessed 2 May 2016. http://r1.ufrrj.br/esa/V2/ojs/index.php/esa/article/ view/349/345.

15 Currently, the Law is established by Resolutions no. 26/2013 
However, even with the use of the bid exemption for family agriculture, the EEs still fail to fulfil the targets for family farming purchases, and create excessively bureaucratic and non-flexible procedures for these farmers. In that sense, EEs do not correctly elaborate these public competitions and insist on subjecting family farmers to the same bidding rules as before. Approaching the reality of the southern states of the country, the municipal PCs were analysed in the year 2013. The total number of calls was 251 , out of which 43 were from Paraná (from 26 municipalities), 94 from Santa Catarina (from 46 municipalities), and 114 from Rio Grande do Sul (from 52 municipalities). It was observed that, in many municipalities, the purchases are still carried out through public biddings (Auctions and Bid Invitation Letters, mainly), because they consider that the bid exemption violates Law 8666/1993 for failing to comply with the principle of price competition and isonomy.

According to FNDE Resolution 26/2013, which regulates the national school feeding programme - PNAE, prices of food items must be included in the PCs and they will be those that are actually paid to FFs. Thus, there is no competition for price among producers, and the choice of competitors is based on tie-breaking criteria such as: location (municipality, territory, state and country, in this order), identification (priority for quilombolas - escaped slaves and their descendants-, indigenous people or settlers), organization (formal over informal and individual), and type of production (ecological over conventional). However, it was observed that many PCs did not contain this information, a situation that is even more noticeable in Paraná and Santa Catarina (where this occurred in $93.0 \%$ and $85.1 \%$ of the cases, respectively).

\footnotetext{
'Oh, and another difficulty is that the purchasing sector understands that the public call does not work at the lowest price, but instead, that the criteria are different. And here is a difficulty, a difficulty of understanding, I think, because Law 8666 is the one taken into account, and, therefore, there is a difficulty to adapt to this specific legislation of PNAE for the public call; these are the difficulties.' (Manager, from RS)
}

In addition to this issue with interpretation of the regulations, it was also observed that the elaboration of Public Calls is not always adequate, leading to obstructions in the execution of purchases. Thus, many

and $04 / 2015$. farmers complain about receiving orders for dispersed deliveries of a low volume of products per receiving point. Further, since the ordered amount of some products is very low, their financial compensation is not favourable. Sometimes, farmers also have to face strikes in schools (farmers from Paraná).

It was verified that, in most of the evaluated PCs from the PR and the RS states, the deliveries were centralized, that is, they occurred at only one receiving point. However, more than a quarter of the PCs from the municipalities of Rio Grande do Sul requested deliveries in more than 10 points, which encumbers the logistic costs for FFs. Still, what is even more concerning is the omission of this information in those PCs notices, which was evidenced in more than $60 \%$ of them in Santa Catarina and almost 30\% in Paraná.

Another analysis performed with the PCs addressed the periodicity of delivery of the products. In Rio Grande do Sul, more than $38 \%$ of the notices estimated weekly deliveries, followed by fortnightly deliveries $(37.7 \%)$. However, once again, the lack of information is noteworthy in the notices from SC and PR, with $78.7 \%$ and $93 \%$ of PCs, respectively, missing such data. This is another problem that, together with the issue of decentralization of deliveries, has an impact on logistic costs, since it is not only necessary to know how many units will be delivered, but also how many times this will be done during the period of validity of the Contract. In a study by Da Silva et al. $(2016)^{16}$, it was verified that the cost of transportation is the most substantial of all other logistic costs.

These data show the difficulties still experienced by municipalities in developing a PC. This is detrimental not only to the EEs themselves, but especially to the farmers, who are deprived of information to support their feasibility assessment for their participation or not in PNAE. Information on the price to be paid for products, the number of receiving places and the periodicity of deliveries would facilitate the decision of the farmer to commit to supply certain products, considering the logistics, the frequency, the quantity that should be delivered, the dates and at what price. These issues are

16 Da Silva, W.H., F.O. Leitão, M.A. Da Silva \& V.S. Brandão. 2016. "Custos logísticos associados ao comércio institucional de alimentos na agricultura familiar: o caso do Programa Nacional de Alimentação Escolar (NSFP).” Anais do $54^{\circ}$ Congresso da Sociedade Brasileira de Economia, Administração e Sociologia Rural: Maceió, Alagoas 
essential to a good organization of FFs and to the cost benefit analysis, which measures the process' efficiency.

In Rio Grande do Sul - the state with the highest rates of compliance with article 14 - many managers considered that they were able to change the perceptions of the legal and purchasing sectors with consultation to other city offices, and through a continuous convincing process.

(...) So a working group of segments was created; who should be in it? Then, we told the department of education, EMATER (Technical Assistance and Rural Extension Company) and involved especially the personnel in the biddings, the finance department; and from there we held meetings every 15 days, and then we grew more and more... Then we realized who hindered the process, what delayed the public call... We involved the city's attorney, who was invited to attend the meetings, and when she understood the law, she changed the whole scenario. She understood that it was a law of inclusion of people and not a law of prices ${ }^{117}$. (Rural Extension, RS).

Therefore, the Brazilian experience reflects that, in places where the actors' and institutions' understanding of the concept of "best value" and sustainable public procurement is clearer, processes are more likely to succeed. Therefore, it is also important to understand which difficulties in this process hinder these changes to purchase products from FFs and how the social actors engage and formulate strategies to overcome them.

\section{Given that the Law exists, Why is it not OBEYED?}

As evidenced in the previous section, the change in PNAE's legislation was based on microstructural changes (local experiences of direct purchases from FFs) and social participation in public policies through Management Councils, such as the Council of Food and Nutrition Security (which culminated in the creation of the PAA). In addition, this change has only been progressing from a perspective of prioritizing "best price" towards considering "best value", because of the dialogue and understanding between the actors. Therefore, it is argued that the actors' actions are fundamental in the change of structures, and without their mobilization, the structure by itself is not modified. In that sense,

17 Passage highlighted by the author not only was the legal framework of PNAE modified by social action, but, without this social action, the legislation in force would not be sustainable or effective. In order to give more substance to this point, qualitative data in the form of interviews was analysed in the municipalities of the three states studied. From the data collected, information was organized according to two categories: issues concerning the action of the "demand organization" (represented by EEs) and issues concerning the action of the "supply organization" (represented by FFs). Within those categories, the crucial issues that prevented or harmed the process and the forms that some municipalities found to solve them were investigated.

Regarding the demand organization, problems and their respective solutions concerning planning, financial and personnel issues were observed.

One aspect considered important in planning was the elaboration of the menus. Many farmers reported that the nutritionists planned the menu without discussing it with them and, also, that nutritionists did not understand that family agriculture does not have the same operation dynamics as supply centres (CEASAs) - which make all products available in large quantities, at any time of the year, and with uniform standards. At the same time, nutritionists stressed that it was difficult to know what was produced in the municipality and in the region, who were the supplying FFs and, therefore, it was difficult to map the local production and adjust their menus to it (nutritionists from Paraná).

The proposed solution to this problem was to change the menus according to the local farmers' production, adapting to the supply: 'The first thing was to get to know the reality of the municipality, to see what I had, and then start to think what I could add to the menu' (Nutritionist, from SC). Thus, the managers had to map the supply they had in the municipality and, from the dialogue with the FFs, to think about the menu and the shopping list. This close contact with the FFs also allowed the adaptation of the logistics, so that the deliveries were possible. In this aspect, PCs were reviewed by considering the number and places of delivery and the quantity of products, to avoid losses to the FFs and to foster their interest in participating in sales to PNAE.

Another problem that affected the organization of demand was the limited financial resources destined for school feeding by the various State bodies (federal, 
state and municipal governments), the limited number of professionals to work in the sites, and the lack of adequate structure in school kitchens and warehouses of EEs (managers from Paraná). These problems often jeopardize the purchase of family farming products, since it is necessary to ration resources, to purchase products that require less handling and less processing in the kitchens, and require less storage space in the warehouses. Additional municipal resources for investment in the physical structure of kitchens and warehouses have also been mentioned in the interviews as a facilitator in this process. Also, in some cases, the EEs began to pay for transportation (purchase of vehicles to collect food on the properties) and even packaging (managers from SC) so that the products were purchased at a lower price.

A final point that compromised the organization of demand for family farming products concerned personnel issues. Thus, there were reports of resistance from nutritionists, cooks and even teachers or principals who considered that purchasing from these suppliers required more dedication, time and work and that their products were not always of 'good quality' (CSF, Farmers and Managers from PR). In addition, the various sectors of the municipality's administration did not establish a dialogue to carry out the planning, organise public procurement and overcome the problems and challenges that were posed. On the other hand, the CSF was mentioned in all the states as being little engaged and active. Thus, the possibility of it being a suitable place for debates, dialogues, contacts and problem solving, has proved underutilized ${ }^{18}$.

Two points stand out as forms of overcoming this issue: investing in educational initiatives for the actors involved, and in intersectoriality - in other words, the dialogue between the sectors. Concerning the first point, many municipalities highlighted the importance of training nutritionists, cooks, counsellors, managers, rural extension practitioners and farmers to know the laws, to be motivated and to work together. Such trainings took place in partnership with several agencies such as Collaborating Centres for School Feeding and Nutrition (CECANES), Universities, Non-Governmental Organizations (NGOs), etc. or from the initiative of the

18 It should be noted that a specific study in the state of Paraná (Triches \& Kilian 2016) identified that in the majority of municipalities where the purchases of family farming products were larger, the CFSs were more active. municipalities themselves. Regarding intersectoriality, relationships among departments such as Agriculture, Health, Education, Administration, and others, were established to solve various problems: 'In the development of this proposal, I believe that this engagement and the will to get things done are important; team work makes a difference' (Manager, from PR).

In terms of organisation of supply, four thematic categories were considered: planning, administrative/bureaucratic aspects, financial and personnel issues.

Regarding the planning problems in the organization of supply by FFs, several points were identified in the interviews. Some are difficult to resolve, such as the climatic interferences that can invariably hamper food production, leading to crop failures and irreparable losses to FFs. This influence of nature on agriculture also impacts on other issues that were raised, such as product quality, regularity and the diversity of products available. There were several mentions to these matters by managers, nutritionists, and rural extension practitioners, regardless of the state they were from - 'there is a lack of family farmers with production quantity and diversity to supply school meals.' This report leads to the interviewees' assertions that farmers are not organized among themselves, nor is their own production. Further, they are resistant to adjusting their conditions to the requirements of the institutional market. Many respondents considered FFs to be individualistic and not open to forming associations and cooperatives, which would hinder their insertion in this market, since the planning of production, logistics, commercial transactions, among other issues, would be facilitated within these spaces.

However, in many cases, it was considered that forming cooperatives, informal associations and groups or joining existing ones was the way farmers found to facilitate their participation in institutional sales. Not only were these organizations stimulated by PNAE's legislation itself and preferred by managers; but they also served to join forces, to increase the diversity and quantity of products supplied, to minimize logistic costs and to delegate the administrative and bureaucratic processes. This last item would be done by relying on the people in charge in the cooperative or association itself, or by outsourcing these administrative and bureaucratic services.

Regarding the administrative/bureaucratic aspects, difficulties arose in obtaining the Declaration of 
Aptitude to Pronaf ${ }^{19}$ (DAP) - which is one of the documents required for the farmer to participate in the PC process - and in elaborating the sales project for school feeding. Another bureaucratic barrier was the different sanitary, environmental and fiscal legislations. Many FFs reveal they do not know the paths they must take to legalize their agroindustries. What is the difference between legalizing a dairy industry and a baking industry, for example? They have different sanitary requirements and different registration bodies. This legal/ bureaucratic entanglement is still not well understood and well known and, when it is, FFs may not consider formalization to be advantageous, since the regulations require adjustments that at times are not worthwhile from a financial point of view. The same occurs in the case of organic certification. It was verified in the interviews that some municipalities purchased organic, but they were not always certified. When asked about that, it was observed that the FFs had difficulties, even in participatory certification processes, in obtaining such document.

To overcome the administrative/bureaucratic problems, it was verified that FFs sought external partnerships with Universities, EMBRAPA (Brazilian Agricultural Research Corporation), Rural Extension Companies and Sebrae (Brazilian Service of Support to Micro and Small Businesses). These partnerships contributed with knowledge and information to make documentation feasible for formalizing their products for organic certification, sanitary inspection, and for starting informal groups to access the PNAE, among other actions.

If one of the problems of the organization of demand was the scarcity of financial resources, in the organization of supply, these funds were even more limited. As evidence for this argument, the FFs mentioned input prices and logistic costs (transportation, packaging, storage and taxes) as strongly influencing the price of the end products. On the other hand, they considered that the prices paid and the per capita amount they can access per year are often low. When equating costs and gains, they argue that participating in this market is not always attractive, which would partly explain the lacking offer of FFs and products, which managers/ nutritionists/CSFs complain about. Even so, many farmers have begun to invest more in logistic processes, mainly to be able to responsibly manage the deliveries and requirements of this market. They have also sought other policies to obtain loans and credit.

'The cooperative also had to adapt to be able to supply for school feeding. We had to rent a shed to build the warehouse, buy trucks to deliver the food' (Family farmer, from SC).

Finally, some personnel issues such as political conflicts and disagreements, distrust of FFs in the state, precarious rural extension and lack of communication between FFs and managers arise. Therefore, all municipalities feel to a lesser or greater degree these interventions, which may lead to greater success or simply to empty institutional sales to PNAE as a policy.

Hence, it is no coincidence that many FFs are afraid and distrustful when the markets they access are susceptible to political conflicts. Moreover, this distrust is based on the history of FFs' relations with the state and its unstable policies. Hence, relying on the state can be very risky for their reproduction and their family (selling products without payments and taking losses), which causes FFs to ponder carefully before jeopardizing their family stability. That may also explain, at least in part, their choice to join an association or cooperative. The distrust in the state is increased if they do not know this market. In most cases, FFs know the informal markets or use intermediaries to sell their products, getting scarcely involved with the commercial issues. Therefore, the many rules and requirements of PNAE are not always known by farmers, which makes them not access it. When they do, they get disappointed with the several requirements to be met, which are unrelated to their daily life, and give up applying for it.

Accordingly, it was necessary to make the farmer understand well the operation of the Programme and trust the State. Several municipalities mentioned moments in which FFs were called to participate in activities to involve them, motivate them, and give them support regarding the issues of production, processing and marketing of their products. More than that, efforts were needed to captivate FFs, by assuring them confidence in the process.

'Well, this is a long path, a long path of a lot of dialogue, of trust too, because we have to make these farmers - the new ones that we want to call believe that they are going to be paid, that they can negotiate with the City; anyway, but that's the path' (Manager, from RS).

19 PRONAF is a credit policy for FFs. 
To close this section, another unanimity in the several municipalities analysed (with the exception of the ones in Rio Grande do Sul) is the precariousness of rural extension as a facilitator of the organisation of production, but not as a mediator of the process. In many places was widely cited as one of the important actors to enable Article 14, given its role in the articulation between producers and managers. However, it has failed to provide technical assistance to farmers.: 'I would need more incentive with the technical assistance, because we feel quite lacking it' (Farmers, from SC). Several FFs think it is a shame that they do not have such assistance in relation to the production and marketing of their products from the Technical Assistance and Rural Extension entities (ATER). Even the state ATER entities themselves are precarious in terms of personnel and the material conditions for doing so.

Thus, it is verified that in order to overcome the difficulties listed above, several strategies are required from the involved actors, who gather interventions in both the demand and the supply dimensions. Each reality is unique, but the points discussed here are common to many of the experiences analysed, and therefore indicate that, beyond legal frameworks, successful experiences rely on actors with power of agency ${ }^{20}$ - who can change structures and institutions through their strategies.

In the meantime, although there have been changes in the legislation of PNAE, and the actors' actions are largely a result of the efficiency of the process, the permeability of the State is essential to the success of the the Programme. As previously seen, policies and legislation on sanitation, taxes, organic certification, financing and rural extension are still necessary, as well as other agrarian and agricultural policies that have not been carried out in a concomitant and adequate manner.

\section{EfFICACY OF THE POLICY IN PROMOTING FOOD AND NUTRITION SECURITY FOR THE PEOPLE INVOLVED}

In addition to the efficiency of the process of purchasing products from family agriculture for PNAE, it is also important to identify the efficacy of this poli-

20 Long, N. 2007. Sociología del desarrallo: una perspectiva centrada en el actor. Mexico: COLSAN/CIESAS. cy regarding the achievement of its objectives. That is, does it provide food and nutrition security for the people involved in it?

Regarding the food and nutritional security of FFs, we sought to identify if access to this market offered financial security. According to the FFs themselves, PNAE provided security and stability in their income. However, the increase was not so substantial, given the limits of sales established by the programme's legislation (BRL 20,000.00 per year) and prices, which were not always attractive. This information corroborates with other studies ${ }^{21}$ that demonstrate the economic advantage that the FFs have in accessing institutional markets. However, there is still a need for quantitative data to verify more accurately what this accounts for.

Regarding the sales limit that the FFs have in relation to PNAE, it must be considered that, when this policy was designed, the opening of the institutional markets for this target group was placed as a gateway to formal markets or as complementary income, intending to cover as many farmers as possible. According to a study by UNDP $(2015)^{22}$, the estimated number of FFs that have sold to PNAE in 2013 (considering the amount used for that purpose in that year and the limit amount per capita) is of only 28,216 individuals, or approximately $1,3 \%$ of Brazilian FFs. Therefore, the coverage of this policy is still small, which damages the financial security and consequently the FNS of this target group.

Regarding the food and nutritional security of schoolchildren, this study sought to evaluate the type of product that was being purchased from FFs through the analysed PCs. Notably, family farming is characterized by producing, for the most part, in natura or mini-

21 See: Triches, R.M. \& S. Schneider. 2010. Alimentação Escolar e Agricultura Familiar: reconectando o consumo à produção. Saúde e Sociedade, 19(4): 933-945. Accessed 10 January 2016. doi: http:// dx.doi.org/10.1590/S0104-12902010000400019; Bevilaqua, K. \& R.M.Triches. 2014. Implicações da venda de gêneros alimentícios para o Programa de Alimentação Escolar nos aspectos de renda e organização dos agricultores familiares. Revista Segurança Alimentar e Nutricional 21:448-460. Accessed 15 August 2016. doi:http:/ / dx.doi.org/10.20396/san.v21i2.8634474; Szinwelski, N.K., C.R.P.A. Teo, L.S. Gallina; F. Grahl \& C. Filippi. 2015. Implicações do Programa Nacional de Alimentação Escolar (NSFP) na renda e organização de agricultores familiares. Revista Brasileira de Politicas Publicas, 5:220-239. Accessed 10 March 2016. doi: http://dx.doi. org/10.5102/rbpp.v5i3.3279.

22 Programa das Nações Unidas para o Desenvolvimento (PNUD). 2015. Escala de compras públicas de alimentos no Brasil. Working Paper n.134. Brasília: PNUD. 
mally processed products. Hence, the degree of processing of the requested food items was observed in the PCs to verify if they were adequate with regards to the students' health and the production by the FF.

It was verified that, in all the states, more than $80 \%$ of the analysed PCs requested in natura products, which meets the above-mentioned premise. However, Rio Grande do Sul and Santa Catarina had in $71.9 \%$ and $62.8 \%$ of their PCs, respectively, products with a high degree of processing.

This information leads to three possible hypotheses. The first one is that FFs of those states have a potentially higher ability and conditions to enable the processing and, consequently, aggregate value to their products - this is positive from the point of view of increased income for these suppliers. This study and others ${ }^{23}$ indicate the difficulty of the FFs in adapting to the sanitary, fiscal and environmental standards to formalize their products and to access the institutional markets. Thus, processed and animal products produced by FFs are more difficult to be sold to PNAE, as they need to be adapted to the appropriate legislation. Therefore, it is possible that, in those states where purchase of processed food is higher, FFs are more developed in this aspect.

The second hypothesis is that, instead of being a positive point, this finding is a negative point, since the requests for highly processed products would not be compatible with FF production and, therefore, would only show an inconsistency between the demand by EEs and the FFs' supply. This is a hypothesis to be tested in other studies, since it would require the evaluation of what is produced in each place (municipality), to observe the coherence between what is requested and what FFs have to offer.

A third hypothesis refers to consumption aspects. One of the objectives of family agriculture purchasing is to discourage processed food supply and to improve nutritional quality of school meals, benefiting students'

23 See: Triches, R.M \& J.G. Baccarin. 2016."Interações entre alimentação escolar e agricultura familiar para o desenvolvimento local." Em Alimentação Escolar: construindo interfaces entre saúde, educação e desenvolvimento, 89-109. Chapecó: Argos; Triches, R.M. \& S. Schneider. 2012. "Desestruturar para construir: interfaces para a agricultura familiar acessar o programa de alimentação escolar." Estudos Sociedade e Agricultura, 20(1):66-105. Accessed 2 May 2016. http://r1.ufrrj.br/esa/V2/ojs/index.php/esa/article/ view/349/345. health. In this regard, the purchasing of highly processed products would undermine the efficacy of the process and frustrate these goals. Nonetheless, other studies have been carried out in Rio Grande do Sul and Santa Catarina, to identify the quality of school feeding with the purchasing of family farming products. They have found positive results in terms of: 1 . nutrition ${ }^{24}$ and 2. purchasing more recommended products than controlled products ${ }^{25}$, when compared to the purchases from conventional suppliers through bidding processes.

Therefore, it is evident that the Brazilian HGSF strategy has been providing conditions to assure FNS for both beneficiaries - farmers and schoolchildren. However, some issues still need to be further adjusted and studied, aiming to ensure the Programme's efficacy in achieving this goal.

\section{Closing Remarks}

The new legal framework of PNAE in Brazil has promoted, since 2009, a growing investment in the marketing of family agriculture products in the country. In 2016, almost BRL 1 billion were aimed at the purchase of such products. However, this number still covers few FFs and could be higher if all EEs were complying with the Law. This article sought to evaluate the efficiency of this process in the most successful region of the country, by finding out how the municipalities of the southern states have been dealing with the difficulties found.

It was verified that the design and formulation of the instrument used for public procurement still have problems, but also that the social actors and their interactions and dialogues are fundamental for the improvement of these new procedures. Thus, the most evident fragilities appear to be related to the communication between FFs (to get organised among themselves), between managers (intersectoriality), and between

24 Fuhr, A. \& R.M. Triches. 2016. Avaliação da qualidade nutricional de cardápios escolares a partir da aquisição de alimentos da agricultura familiar. Anais do II Encontro Nacional de Pesquisa em Segurança Alimentar e Nutricional: Fiocruz, Brasília.

25 Soares, P., S.S. Martinelli, L. Melgarejo \& S.B. Cavalli. 2013. "Fornecimento de alimentos da agricultura familiar para a alimentação escolar: o exemplo do Programa de Aquisição de Alimentos." Segurança Alimentar e Nutricional, 20(1): 41-51. Accessed 17 February 2016. doi:http://dx.doi.org/10.20396/san.v20i1.8634621. 
producers and consumers. Managers are unaware of the farmers' problems and vice versa, and it was identified in several interviews that they blame one another for the lack of legal compliance within the Programme.

In the wake of this argument, in the qualitative study of municipalities of these three southern states, it was verified that a good part of the difficulties listed were overcome because of the strategic action of social actors. However, in addition to this social interaction, it is found that many other issues depend on the intervention of the State to be resolved. Other regulatory frameworks should be reviewed to make the Programme more successful in this regard. For example, the need for ATER to be more structured and more committed to family agriculture, the need for a sanitary legislation that is closer to the reality of the family agroindustry and for greater promotion of organic/agroecological production. The State permeability has a prevailing role for the change in the juridical and political context that is needed to support the legal changes of the Program.

Finally, more research should be conducted to evaluate this policy so that it can have more support and prevalence as a strategy for food security and human rights security, not only in Brazil but also at the global level. Hence, the evidence should be increasingly strengthened so that we have a policy that becomes permanent and consolidated and spreads to other types of public food procurement.

\section{BiBLIOGRAPHY}

Bevilaqua, K. \& R.M.Triches. 2014. "Implicações da venda de gêneros alimentícios para o Programa de Alimentação Escolar nos aspectos de renda e organização dos agricultores familiares." Revista Segurança Alimentar e Nutricional 21:448-460. Accessed 15 August 2016. doi:http://dx.doi.org/10.20396/san.v21i2.8634474.

Brasil. Lei no 11947 de 16 de junho de 2009. 2009. Dispõe sobre o atendimento da alimentação escolar e do Programa Dinheiro Direto na Escola aos alunos da educação básica. Diário Oficial da União. Brasília - DF. Accessed 15 October 2016. http://www.planalto.gov. br/ccivil_03/_ato2007-2010/2009/lei/111947.htm

Burlingame, B. \& S. Dernini. 2012. "Sustainable Diets and Biodiversity: Directions and Solutions for
Policy, Research and Action." Proceedings of the International Scientific Symposium Biodiversity and Sustainable Diets United against Hunger?. FAO Headquarters, Rome: $\mathrm{FAO}$ and Bioversity International.

Bundy, D., C. Burbano, M. Grosh, A. Gelli, M. Jukes \& L. Drake. 2009. Rethinking school feeding: social safety nets, child development, and the education sector. Washington: World Bank Publications.

Da Silva, W.H., F.O. Leitão, M.A. Da Silva \& V.S. Brandão. 2016. "Custos logísticos associados ao comércio institucional de alimentos na agricultura familiar: o caso do Programa Nacional de Alimentação Escolar (NSFP)." Anais do 54 Congresso da Sociedade Brasileira de Economia, Administração e Sociologia Rural: Maceió, Alagoas.

Espejo, F., C. Burbano \& E. Galliano. 2009. Home-Grown School Feeding: A framework to link school feeding with local agricultural production. Rome: WFP.

Food and Agriculture Organization (FAO). 2015. Las compras públicas a la agricultura familiar y la seguridad alimentaria y nutricional em America Latina y el Caribe: lecciones aprendidas y experiências. Brasilia: FAO.

Fuhr, A. \& R.M. Triches. 2016. Avaliação da qualidade nutricional de cardápios escolares a partir da aquisição de alimentos da agricultura familiar. Anais do II Encontro Nacional de Pesquisa em Segurança Alimentar e Nutricional: Fiocruz, Brasília.

Fundo Nacional de Desenvolvimento da Educação (FNDE). 2016. Programa Nacional de Alimentação Escolar. Accessed 10 November 2016. http://www.fnde.gov.br /programas/alimentacao-escolar.

Herrmann, I. 1998. Licitações públicas no Brasil: explorando o conceito de ineficiência por desenho. Anais III SemeAd: USP, São Paulo.

Izumi, B.T., D.W.Wright \& M.W. Hamm. 2010. "Market diversification and social benefits: motivations of farmers participating in farm to school programs." Journal of Rural Studies, 26:374-382. Accessed 18 August 2016. http://www.sciencedirect.com/science/article/ pii/S0743016710000161.

International Policy Centre for Inclusive Growth (IPC - IG). 2013. Structured Demand and Smallholder Farmers in Brazil: the Case of FPP and NSFP. Brasilia: IPC$-\mathrm{IG}$.

Long, N. 2007. Sociología del desarrallo: una perspectiva 
centrada en el actor. Mexico: COLSAN/CIESAS.

Morgan, K. 2006. "School Food and public domain: the politics of the public plate." The political quarterly, 77:379-387. Accessed 10 November 2016. doi:10.1111/ j.1467-923X.2006.00809.x.

Morgan, K \& R. Sonnino. 2008. The school food revolution: public food and the challenge of sustainable development. London: Earthscan.

Otsuki, K. 2011. "Sustainable partnerships for a green economy: A case study of public procurement for home-grown school feeding." Natural Resources Forum, 35(3):213-222. Accessed 20 September 2016. doi:10.1111/j.1477-8947.2011.01392.x.

Programa das Nações Unidas para o Desenvolvimento (PNUD). 2015. Escala de compras públicas de alimentos no Brasil. Working Paper n.134. Brasília: PNUD.

Soares, P., S.S. Martinelli, L. Melgarejo \& S.B. Cavalli. 2013. "Fornecimento de alimentos da agricultura familiar para a alimentação escolar: o exemplo do Programa de Aquisição de Alimentos." Segurança Alimentar e Nutricional, 20(1): 41-51. Accessed 17 February 2016. doi:http://dx.doi.org/10.20396/san.v20i1.8634621.

Sonnino, R., T.L. Bassinello \& C. Lozano. 2016. "School Feeding Programmes: addressing the challenges of sustainable development." In Alimentação Escolar: construindo interfaces entre saúde, educação e desenvolvimento, 35-64. Chapecó: Argos.

Szinwelski, N.K., C.R.P.A. Teo, L.S. Gallina; F. Grahl \& C. Filippi. 2015. "Implicações do Programa Nacional de Alimentação Escolar (NSFP) na renda e organização de agricultores familiares." Revista Brasileira de Politicas Publicas, 5:220-239. Accessed 10 March 2016. doi: http://dx.doi.org/10.5102/rbpp.v5i3.3279.

Thies, V.F., C. Grisa, S. Schneider \& W. Belik. 2016. Potencial das compras públicas como mercado para a agricultura familiar - uma análise do NSFP entre 20112014. Anais do $54^{\circ}$ Congresso da Sociedade Brasileira de Economia, Administração e Sociologia Rural: Maceió, Brazil.
Triches, R.M \& J.G. Baccarin. 2016.“Interações entre alimentação escolar e agricultura familiar para o desenvolvimento local." Em Alimentação Escolar: construindo interfaces entre saúde, educação e desenvolvimento, 89109. Chapecó: Argos.

Triches, R.M. \& L. Kilian. 2016. "Papel dos atores sociais na aquisição de produtos da agricultura familiar para alimentação escolar em municípios paranaenses." Redes, 21(3): 159 - 179. Accessed 19 December 2016. doi: http://dx.doi.org/10.17058/redes.v21i3.7055 .

Triches, R.M. \& S. Schneider. 2010. "Alimentação Escolar e Agricultura Familiar: reconectando o consumo à produção." Saúde e Sociedade, 19(4): 933-945. Accessed 10 January 2016. doi: http://dx.doi.org/10.1590/ S0104-12902010000400019

Triches, R.M. \& S. Schneider. 2012. "Desestruturar para construir: interfaces para a agricultura familiar acessar o programa de alimentação escolar." Estudos Sociedade e Agricultura, 20(1):66-105. Accessed 2 May 2016. http://r1.ufrrj.br/esa/V2/ojs/index.php/esa/article/ view/349/345.

\section{ACKnowledgements}

I gratefully acknowledge the support of the CNPq, without which the present study could not have been completed. I would like to thank my colleagues who participated in the projects that originated this article, for helping me in developing the ideas presented here. 
Para publicar na Revista de Direito Internacional, acesse o endereço eletrônico www.rdi.uniceub.br ou www.brazilianjournal.org.

Observe as normas de publicação, para facilitar e agilizar o trabalho de edição. 